\title{
Penerapan Metode Simulasi untuk Meningkatkan Prestasi Belajar Siswa pada Mata Pelajaran PKn Di Kelas IV SD Negeri 12 Kepahiang
}

Senawati

SD Negeri 12 Kepahiang

\begin{abstract}
Abstrak
Permasalahan yang terdapat dalam penelitian ini adalah: 1) Prestasi belajar Pendidikan Kewarganegaraan di kelas IV SD Negeri 12 Kepahiang belum memenuhi kriteria ketuntasan belajar secara klasikal, 2) metode pengajaran masih kurang bervariasi. Tujuan penelitian ini, untuk meningkatkan aktivitas siswa dalam pembelajaran Pendidikan Kewarganegaraan melalui penerapan metode simulasi pada siswa kelas IV SD Negeri 12 Kepahiang, untuk meningkatkan prestasi belajar siswa di kelas IV SD Negeri 12 Kepahiang melalui penerapan metode simulasi. Jenis penelitian ini adalah Penelitian Tindakan Kelas (Classroom Action Reasearch) yang telah dilaksanakan dalam dua siklus, setiap siklus terdiri dari 4 tahap yaitu tahap perencanaan, tahap pelaksanaan tindakan, tahap observsi dan tahap refleksi. Instrument yang digunakan terdiri dari lembar observasi guru dan siswa serta lembar tes tertulis dalam bentuk essay.Data tes dianalisis dengan menggunakan rata-rata nilai dan persentase ketuntasan belajar, sedangkan data observasi dianalisis dengan rata-rata skor dan kriteria skor. Hasil dari penelitian ini yaitu pada siklus I diperoleh nilai rata-rata skor observasi guru 27,75 dengan kreteria baik, dan rata-rata skor observasi siswa sebesar 27,25 dengan kreteria baik, pada siklus II rata-rata skor observasi guru meningkat menjadi 30,75 dengan kreteria baik dan rata-rata skor observasi siswa sebesar 30 dengan kreteria baik. Hasil analisis ketuntasan belajar secara klasikal pada siklus I sebesar $38,70 \%$ dengan nilai rata-rata 6,82. Pada siklus II ketuntasan belajar secara klasikal meningkat menjadi 90,32\% diikuti dengan nilai rat-rata yang juga meningkat menjadi 7,95. Dengan demikian dapat disimpulkan bahwa penggunaan metode simulasi dapat meningkatkan prestasi belajar siswa pada mata pelajaran Pendidikan Kewarganegaraan di kelas IV SD Negeri 12 Kepahiang.
\end{abstract}

Kata kunci: Metode, Simulasi, Mata Pelajaran Pendidikan Kewarganegaraan, Prestasi Belajar. 


\section{Pendahuluan}

Pendidikan merupakan kunci untuk semua kemajuan dan perkembangan yang berkualitas, sebab dengan pendidikan manusia dapat mewujudkan semua potensi dirinya baik sebagai pribadi maupun sebagai warga masyarakat. Dalam rangka mewujudkan potensi diri menjadi multiple kompetensi harus melewati proses pendidikan yang diimplementasikan dalam proses pembelajaran. Hal ini sesuai dengan pernyataan bahwa:

Pendidikan adalah usaha sadar dan terencana untuk mewujudkan suasana belajar dan proses pembelajaran agar aktif mengembangkan potensi diri untuk memiliki kekuatan spiritual keagamaan, pengendalian diri, kepribadian, kecerdasan, akhlak mulia serta keterampilan yang diperlukan dirinya, masyarakat dan negara (UUSPN, No 20/2003).

Diperkuat pula oleh Soetandyo Wingnjo Soebroto ( dalam Mulyana) mengemukakan bahwa pendidikan adalah proses terprogram untuk mengefektifkan terjadinya perubahan kognitif dan afektif dalam diri seorang anak Indonesia sedemikian rupa sehingga anak dapat berfungsi dengan baik di dalam masyarakat. Selanjutnya Dinn Wahyudin (2007) mengemukan bahwa pendidikan adalah proses transformasi atau proses perubahan tingkah laku peserta didik. Senada dengan itu menurut Ahmad D. Marimba (dalam Hasbullah 2006) pendidikan adalah bimbingan atau pimpinan secara sadar oleh si pendidik terhadap perkembangan jasmani dan rohani si terdidik menuju terbentuknya kepribadian yang utama.

Berdasarkan pengertian pendidikan di atas peneliti berkesimpulan bahwa pendidikan adalah usaha yang sengaja dilakukan untuk menyiapkan peserta didik melalui kegiatan bimbingan, pengajaran dan latihan bagi peranannya dimasa mendatang yang dapat merubah tingkah laku peserta didik dapat mendewasakan manusia. Hal tersebut memiliki makna bahwa pendidikan diselenggarakan dengan rencana yang matang, mantap, sistematik, menyeluruh, berjenjang berdasarkan pemikiran yang rasional, objektif serta dengan kaidah untuk kepentingan masyarakat dalam arti yang seluasluasnya.

Peranan guru dalam mencapai tujuan pendidikan sangat menentukan. Hal ini sesuai dengan pandangan Wina Sanjaya (2006), peran guru adalah: "Sebagai sumber belajar, fasilitator, pengelola, demonstrator, pembimbing, dan evaluator". Sebagai motivator guru harus mampu membangkitkan motivasi siswa agar aktivitas siswa dalam proses pembelajaran berhasil dengan baik.

Salah satu cara untuk membangkitkan aktivitas siswa dalam proses pembelajaran adalah dengan mengganti cara atau metode pembelajaran yang selama ini tidak diminati lagi oleh siswa, seperti pembelajaran yang dilakukan dengan metode ceramah dan tanya-jawab. Metode pembelajaran ini membuat siswa jenuh dan tidak kreatif.Suasana belajar mengajar yang diharapkan adalah menjadikan siswa sebagai subjek yang berupaya menggali sendiri, memecahkan sendiri masalah-masalah dari suatu konsep yang dipelajari, sedangkan guru lebih banyak bertindak sebagai motivator 
dan fasilitator.Situasi belajar yang diharapkan di sini adalah siswa yang lebih banyak berperan.

Berdasarkan hasil pengamatan guru terhadap siswa kelas IV SD Negeri 12 Kepahiang, dalam mata pelajaran Pendidikan Kewarganegaraan, ternyata siswa kurang antusias dalam pembelajaran dikarenakan guru hanya menggunakan metode ceramah dalam pembelajaran. Metode pembelajaran ini tidak dapat membangkitkan aktivitas siswa dalam belajar.Hal ini tampak dari perilaku siswa yang cenderung hanya mendengar dan mencatat pelajaran yang diberikan guru.Siswa tidak mau bertanya apalagi mengemukakan pendapat tentang materi yang diberikan sehingga pembelajaran Pendidikan Kewarganegaraan cenderung membosankan dan kurang menarik minat siswa.

Agar pembelajaran Pendidikan Kewarganegaraan menjadi lebih efektif maka guru berusaha mencarikan metode pembelajaran lain, sehingga pembelajaran lebih bermakna dan lebih berkualitas. Metode pembelajaran yangakan peneliti coba laksanakan adalah dengan menerapkan metode simulasi. Ketertarikan peneliti menerapkan metode simulasi, karena peneliti beranggapan dalam penerapan metode simulasi semua siswa dapat aktif dan bertanggung jawab dalam pembelajaran baik individu maupun kelompok.Jadi, keunggulan pada metode simulasi ini yaitu seluruh anggota dalam kelompok harus bekerja sesuai dengan tugas yang diberikan, sebab tugas itu ada yang merupakan tanggung jawab individu dan ada pula tanggung jawab kelompok. Oleh sebab itu, dalam penelitian ini peneliti mengambil sebuah judul yaitu:"Penerapan MetodeSimulasi Untuk Meningkatkan Prestasi Belajar Siswa Pada Mata Pelajaran PKn di Kelas IV SD Negeri 12 Kepahiang"

\section{Metode}

Jenis penelitian ini adalah Penelitian Tindakan Kelas (Classroom Action Research) merupakan jenis penelitian yang bertujuan untuk peningkatan pembelajaran melalui serangkaian tindakan yang diikuti dengan refleksi.Kemudian mencobakan dan mempraktikkan secara sistematis mengenai permasalahan di dalam kelas secara reflektif dan berkolaborasi guna meningkatkan keaktifan dalam pembelajaran dan prestasi belajar siswa (Wardani, 2006).

Maka, metode penelitian yang digunakan harus menekankan pada suatu kajian reflektif dan kolaboratif yang bertumpu pada realitas lapangan (natural setting). Berdasarkan pandangan tersebut, penelitian ini menggunakan penelitian tindakan (action research).Dalam penelitian model ini peneliti bukan hanya sekedar memecahkan masalah pembelajaran yang terjadi di kelas, tetapi juga berupaya meningkatkan kepemilikan profesionalisme guru melalui kegiatan reflektif dan kolaboratif. Menurut Arikunto, dkk (2007) jenis penelitian ini adalah penelitian tindakan kelas (Classroom Action Research) merupakan jenis penelitian yang bertujuan untuk memperbaiki mutu praktik pembelajaran di kelas. 
Langkah pertama kegiatan penelitian model ini, diawali dengan melakukan penelitian pendahuluan (observasi). Observasi dilakukan terhadap kelas IV SDN 12Kepahiang. Hasil temuan dari sekolah tersebut dilakukan refleksi untuk menentukan langkah-langkah kegiatan selanjutnya hingga tujuan penelitian tercapai.

Penelitian ini dilaksanakan di SD Negeri 12 Kepahiang untuk pembelajaran Penedidikan Kewarganegaraan, pelaksanaan penelitian ini akan dilakukan bulan Agustus sampai dengan bulan September tahun 2014. Subjek penelitian dalam penelitian ini adalah siswa kelas IV SDN 12 Kepahiang tahun ajaran 2014/2015. Guru dalam penelitian ini adalah bertindak sebagai peneliti. Siswa yang akan diteliti berjumlah siswa 31 orang, yang terdiri dari 17 laki-laki dan 14 perempuan.

Menurut Kunandar (2008) ada 4 tahapan penting dalam melakukan penelitian tindakan kelas yaitu: (1) perencanaan; (2) pelaksanaan; (3) pengamatan; dan (4) refleksi.

1. Perencanaan

Perencanaan adalah persiapan yang dilakukan untuk pelaksanaan Penelitian Tindakan Kelas.Tahap ini diawali dengan kegiatan observasi awal untuk mengidentifikasi masalah sehingga diperoleh permasalahan.

2. Pelaksanaan tindakan

Pelaksanaan tindakan yaitu deskripsi tindakan yang akan dilakukan, langkah kerja tindakan perbaikan yang akan dikerjakan dan prosedur tindakan yang akan diterapkan.

3. Pengamatan atau Observasi

Pengamatan atau observasi yaitu proses perekaman data mengenai proses dan produk dari implementasi tindakan yang dirancang.

4. Analisis dan Refleksi

Berupa uraian tentang prosedur analisis terhadap hasil pemantauan dan refleksi berkaitan dengan proses dan dampak tindakan perbaikan yang dilaksanakan, serta kriteria dan rencana bagi tindakan siklus yang berikutnya. Refleksi dilakukan oleh peneliti dengan cara berdiskusi dengan teman sejawat beserta guru Pendidikan Kewarganegaraan tentang pelaksanaan tindakan yang telah dilaksanakan untuk menentukan tindakan yang akan dilakukan selanjutnya.

Menurut prosedur Penelitian Tindakan Kelas, maka penelitian ini dilaksanakan dalam bentuk siklus yang terdiri dari empat tahap yaitu: perencanaan (planning), tindakan (action), pengamatan (observing), dan refleksi (reflecting). Sebelum melakukan siklus pertama, peneliti melakukan kegiatan pra siklus yang mencakup observasi dan pengenalan kelas yang dilanjutkan diskusi dengan guru untuk mengetahui sejauh mana siswa menguasai konsep yang akan diberikan.

\section{Hasil dan Pembahasan}

\section{Pra siklus}

Pelaksanaan pembelajaran pada pra siklus dilaksanakan tidak menggunakan metode simulasi, observasi dilakukan dengan mengamati satu kali pertemuan pada materi pokok "Mengenal Sistem Pemerintahan Desa". 
Pelaksanaan pembelajaran dilakukan dengan tiga tahap kegiatan yaitu kegiatan pendahuluan, kegiatan inti, dan kegiatan penutup.

Hasil observasi terhadap aktivitas siswa dalam proses pembelajaran pada pra siklus yang dilakukan oleh guru diperoleh rata-rata skor 24,5 dengan kategori cukup. Pada akhir pembelajaran dilakukan tes untuk mengetahui tingkat keberhasilan belajar siswa dalam pembelajaran Pendidikan Kewarganegaraan belum menggunakan metode simulasi. Nilai rata-rata yang diperoleh siswa pada pra siklus 6,19 dengan persentase ketuntasan 25,80\%. Hasil belajar ini belumlah mencapai ketuntasan belajar Pendidikan Kewarganegaraan yang seharusnya, sebab pembelajaran Pendidikan Kewarganegaraan dikatakan tuntas apabila hasil belajar siswa mencapai nilai minimal 7 dan ketuntasan belajar siswa minimal 85\%.

\section{Siklus I}

Berdasarkan pembelajaran yang telah dilakukan pada pra siklus maka penelitian dilanjutkan kembali dengan melaksanakan siklus I, pada siklus I dapat dilihat bahwa terjadi peningkatan dari aktivitas siswa.setelah dilakukan siklus I dengan menerapkan pembelajaran Pendidikan Kewarganegaraan dengan metode simulasi keaktifan siswa mengalami peningkatan, ini dapat di lihat dari pra siklus untuk keaktifan siswa nilai rata-rata adalah 24,5 dengan kategori cukup, sedangkan untuk siklus I nilai rata-rata keaktifan siswa 27,25 dengan kategori baik

Prestasi belajar siswa setelah diberi tindakan yang berupa pelaksanaan pembelajaran Pendidikan Kewarganegaraan dengan metode simulasi juga mengalami peningkatan. Hal ini terlihat dari nilai rata-rata pada saat pra siklus adalah 6,19 dengan persentase ketuntasan $25,80 \%$, pada siklus I nilai rata-rata meningkat menjadi 6,82 dan persentase ketuntasan belajar klasikal $38,70 \%$. Pada siklus I ini nilai rata-rata dan persentase ketuntasan belajar klasikal belum bisa dikatakan tuntas.Sehingga perlu dilakukan siklus penelitian selanjutnya.

Berdasarkan lembar observasi yang telah dinilai oleh gurru ada beberapa aspek observasi siswa yang telah tercapai, yaitu sebagai berikut : (1) motivasi siswa dalam mengikuti pembelajaran yang disampaikan sudah bagus; (2) siswa sudah mendengarkan penjelasan dari guru; (3) keterampilan siswa dalam bersimulasi sudah bagus; (4) siswa sudah mengerjakan evaluasi yang diberikan oleh guru sesuai dengan petunjuk dari guru.

Selain itu juga hal-hal yang belum tercapai pada observasi siswa antara lain: (1) siswa kurang menanggapi apersepsi yang diberikan guru; (2) siswa kurang aktif dalam kegiatan tanya jawab; (3) siswa kurang berpartisipasi aktif dalam kelompok simulasi;(4) siswa kurang berkerjasama dalam kelompoknya; (5) siswa menyajikan hasil simulasi belum optimal.

Berdasarkan hasil dari observasi tersebut, maka hal-hal yang harus diperbaiki oleh guru pada kegiatan pembelajaran dengan menerapkan pembelajaran Pendidikan Kewarganegaraan dengan menggunakan metode simulasi adalah sebagai berikut: (1) siswa seharusnya menanggapi apersepsi yang diberikan oleh guru, hendaknya guru dalam memberikan apersepsi dan motivasi dengan cara memberikan pertanyaan lanjut agar siswa dapat 
menanggapi apersepsi yang diberikan oleh guru; (2) guru seharusnya dapat menggali keingintahuan anak sehingga siswa menjadi aktif dalam kegiatan tanya jawab; (3) siswa harus lebih berpartisipasi aktif lagi dalam kegiatan simulasi dengan cara guru membimbing dan mengawasi siswa sehingga siswa dapat lebih aktif lagi; (4) seharusnya siswa berkerja sama dalam kelompoknya, disini guru harus lebih mengawasi kelompok siswa; (5) guru harus lebih membimbing siswa dalam penyajian hasil simulasi sehingga siswa dapat menyajikan hasil simulasi secara optimal.

\section{Siklus II}

Setelah melakukan refleksi terhadap pelaksanaan siklus I, dan melakukan perbaikan-perbaikan dalam pembelajaran diperolehlah hasil observasi terhadap aktivitas guru yang memperoleh skor 30,75 dengan kategori sangat baik, kemudian juga dilakukan observasi terhadap keaktifan siswa pada siklus II yang memperoleh skor 30 dengan kategori baik, selain itu juga hasil belajar siswa pun meningkat setelah menerapkan pembelajaran Pendidikan Kewarganegaraan dengan metode simulasi yaitu nilai rata-rata hasil belajar dan persentase ketuntasan belajar klasikal adalah untuk mata 7,95 dan persenttase ketuntasan belajar klasikal 90,32\%.

Dari hasil penelitian yang telah dilaksanakan yang terdiri dari pra siklus, siklus I dan siklus II dengan menggunakan metode similasi pada pelajaran Pendidikan Kewarganegaraan di kelas IV SD Negeri 12 Kepahiang , berjumlah 31 orang siswa terdiri dari 17 orang siswa laki-laki dan 14 orang siswa perempuan, terdapat peningkatan proses pembelajaran dari pra siklus, siklus I dan siklus II, seperti yang telihat pada rata-rata skor observasi aktivitas guru dan observasi aktivitas siswa dan nilai rata-rata kelas serta persentase ketuntasan belajar klasikal dari pra siklus, siklus I dan siklus II seperti terlihat pada tabel 11 di bawah ini.

\begin{tabular}{|c|c|c|c|c|}
\hline \multirow{3}{*}{ Siklus } & \multicolumn{2}{|c|}{$\begin{array}{c}\text { Rata-rata Skor } \\
\text { Observasi }\end{array}$} & $\begin{array}{c}\text { Nilai Rata-rata } \\
\text { Kelas }\end{array}$ & $\begin{array}{c}\text { Peresentase Ketuntasan } \\
\text { Belajar Klasikal }\end{array}$ \\
\cline { 2 - 3 } & \multicolumn{2}{|c|}{ Siswa } & & \\
\cline { 2 - 3 } & Skor & Ktr & & \\
\hline Pra & 24,5 & C & 6,19 & $25,80 \%$ \\
\hline I & 27,25 & B & 6,82 & $38,70 \%$ \\
\hline II & 30 & B & 7,95 & $90,32 \%$ \\
\hline
\end{tabular}

\section{Kesimpulan}

Berdasarkan temuan hasilpenelitian yang telah dikemukakan, maka dapat diambil beberapa kesimpulan sebagai berikut:

1. Penerapan metode simulasi pada pembelajaran Pendidikan Kewarganegaraan dapat meningkatkan aktivitas belajar siswa di kelas IV SD Negeri 12 Kepahiang. Hal ini terlihat dari peningkatan perolehan skor terhadap aktivitas siswa yaitu 24,5 dengan kategori cukup pada pra siklus meningkat menjadi 27,25 dengan kategori baik pada siklus I dan meningkat lagi menjadi 30 dengan kategori baik pada siklus II. 
2. Penerapan metode simulasi pada pembelajaran Pendidikan Kewarganegaraan dapat meningkatkan prestasi belajar siswa di kelas IV SD Negeri 12 Kepahiang. Hal ini ditandai dengan peningkatan nilai rata-rata dan persentase ketuntasan belajar siswa secara klasikal dari pra siklus, siklus I, dan siklus II sebagai berikut: pada pra siklus nilai rata yang diperoleh 6,19 dan persentase ketuntasan belajar klasikal $25,80 \%$ meningkat menjadi 6,82 untuk nilai rata-rata dan $38,70 \%$ untuk persentase ketuntasan belajar secara klasikal pada siklus I dan pada siklus II mengalami peningkatan lagi menjadi 7,95 untuk nilai rata-rata dan $90,32 \%$ untuk persentase ketuntasan belajar secara klasikal.

Agar proses pembelajaran dapat berjalan dengan baik dan tujuan yang diinginkan akan tercapai maka disarankan:

1. Bagi guru Pendidikan Kewarganegaraan, diharapkan dapat menerapkan metode simulasi dalam pembelajaran sebagai salah satu cara untuk meningkatkan prestasi belajar siswa dalam proses pembelajaran. Tetapi penggunaan metode simulasi ini harus disesuaikan dengan waktu dan materi pelajarannya.

2. Bagi siswa, diharapkan dapat mengikuti kegiatan pembelajaran dengan baik sehingga tujuan pembelajara dapat dicapai.

3. Bagi Diknas, Tindakan Penelitian dengan penerapan metode simulasi dapat dijadikan masukan bagi guru-guru terutama guru bidang studi Pendidikan Kewarganegaraan dalam rangka untuk meningkatkan kualitas dan prestasi belajar siswa.

\section{Referensi}

Azhar, L, M. 1993. Proses Belajar mengajar. Jakarta: Sinar Baru

Dimyati dan Mudjiono. 2006. Belajar dan Pembelajaran. Jakarta: Reneka Cipta

Dinn Wahyudin, dkk. 2007. Pengantar Pendidkan. Jakarta: Universitas Terbuka

Djamarah, S, B. 1994.Psikologi Belajar. Jakarta: Renika Cipta

Hasbullah. 2006. Dasar-dasar Ilmu Pendidikan. Jakarta: Raja Grafindo Persada

Hasibuan, J dan Mudjiono. 2000. Proses Belajar Mengajar. Bandung: Rosda Karya

Mikarsa dan Hera Lestari, dkk. 2004. Pendidikan Anak di SD. Jakarta: Universitas Terbuka

Mulyana, 2003.Pengantar Pendidikan, Jakarta: Balai Pustaka

Mulyasa, 2007.Menjadi Guru Profesional, Bandung: remaja Rosdakarya

Hamalik Oemar, 2001, Proses Belajar Mengajar, Jakarta, P.T., Bumi Aksara

Soetomo. 1993. Dasar-dasar Interaksi Belajar Mengajar. Surabaya: Usaha Nasional 
Wardani, 2006.PenelitianTindakan Kelas, Jakarta: Universitas terbuka

Wina Senjaya, 2006, Strategi Pembelajaran Berorientasi Proses Standar ProsesPendidikan, Jakarta : Kencana Prima

Winataputra Udin, S. 2007. Materi dan Pembelajaran PKn SD, Jakarta: Universitas Terbuka 